\title{
A new freeware program for the Probability of Success calculation of new gas discoveries within the Croatian part of the Po depression
}

The Mining-Geology-Petroleum Engineering Bulletin UDC: $550.8: 004.42$

DOI: 10.17794/rgn.2017.2.6

Preliminary communication

\author{
Mate Režić' ${ }^{1}$ Andrija Varenina ${ }^{2}$ \\ ${ }^{1}$ Alojzija Stepinca 16 Street, 21000 Split, Master of Geology \\ ${ }^{2}$ Jabuka 9 Street, 21240 Trilj, Master student, University of Zagreb, Faculty of Mining, Geology and Petroleum Engineering, \\ Dept. for Geology and Geological Engineering, Pierottijeva 6, 10000 Zagreb
}

\begin{abstract}
:
The aim of this paper is to introduce an application in the form of a transparent freeware program which can be used for the assessment of the Probability of Success (abbr. POS, also POS and geological probability are synonyms) in finding new gas discoveries within the Croatian part of the Po depression. A deterministic approach is applied and includes five geological categories (traps, reservoirs, source rocks, migration and hydrocarbon preservation) with certain geological events that depend on the geological settings of the Northern Adriatic subsurface. The chosen probability classes include five, three or two numerical and textual values as follows: 1.00 for certain, 0.75 for very probable, 0.66 and 0.50 for reliable / probable, 0.33 and 0.25 for unreliable / low probable and 0.05 for not proven / improbable events. The program is made as an improvement in the sense of faster calculation according to a previous assessment that was based on a previously published Croatian model of the POS using Microsoft Excel and GeoProbe Modeling 1.1 program as an example, which is used to calculate the geological probability of hydrocarbon discoveries for the Croatian part of the Panonian Basin System. The program is in English and it is done in the C\# programming language.
\end{abstract}

Keywords

The Northern Adriatic, assessment of probability, C\# programming, geological categories, probability classes.

\section{Introduction}

In Croatia, for the calculation of geological risk (probability) a well known deterministic process was already used for hydrocarbon discovery in existing or new plays and prospects in the Drava Depression (Malvić, 2003). Such procedure of calculating the POS can, with smaller or bigger modifications, be applied to almost all reservoirs in any oil and gas basin or depression, but it is necessary to geologically define the area in which such a calculation is made (Malvić, 2009). Geologically defining the area is crucial because geological events with probabilities depend on it. Geological probability, mathematically, is a simple deterministic product of probabilities related to several geological categories, and the final result is the assessment of the new hydrocarbon discoveries which is shown as a percentage (\%).

\section{Study area}

Gas fields near the southwestern coast of Istria were given names: Ida, Ana, Vesna, Irina, Annamaria, Ivana and Ika and they form the Northern Adriatic exploitation area. The Izabela Field makes the Izabela exploitation

Corresponding author: Mate Režić

mate.rezic92@hotmail.com area and the Marica and Katarina Fields together form the Marica exploitation area. The Ika, Ivana, Marica, Annamaria Fields are larger and more important while the Ida, Irina, Irma, Ksenija, Katarina, Izabela and Koraljka Fields are smaller (see Figure 1). The hydrocarbon explorations resulted in the discovery of gas reservoirs in the sediments of the Pleistocene. Gas is located in the loose sands that are a few meters thick and at depths from 500 to $1000 \mathrm{~m}$ (Velić, 2007). The Ika Gas Field is the only field in the Adriatic with gas accumulated in mesosoic carbonate rocks which are located under an uncomformity under 1000 meters.

All Croatian gas reservoirs in the Adriatic are located in the eastern marginal area of the Po depression (see Figure 2). Detritus is originally from the Alps and the total thickness of the Po depression may locally be higher than 6,000 meters in the Italian section (e.g. Malvić et al., 2011).

\section{Observed litostratigrafic intervals in Northern Adriatic hydrocarbon exploration (Mali Alan, Istria and Ivana Formations)}

Fractured Mesozoic limestones belong to the Mali Alan Formation (Velić et al., 2015). Lithotypes region- 


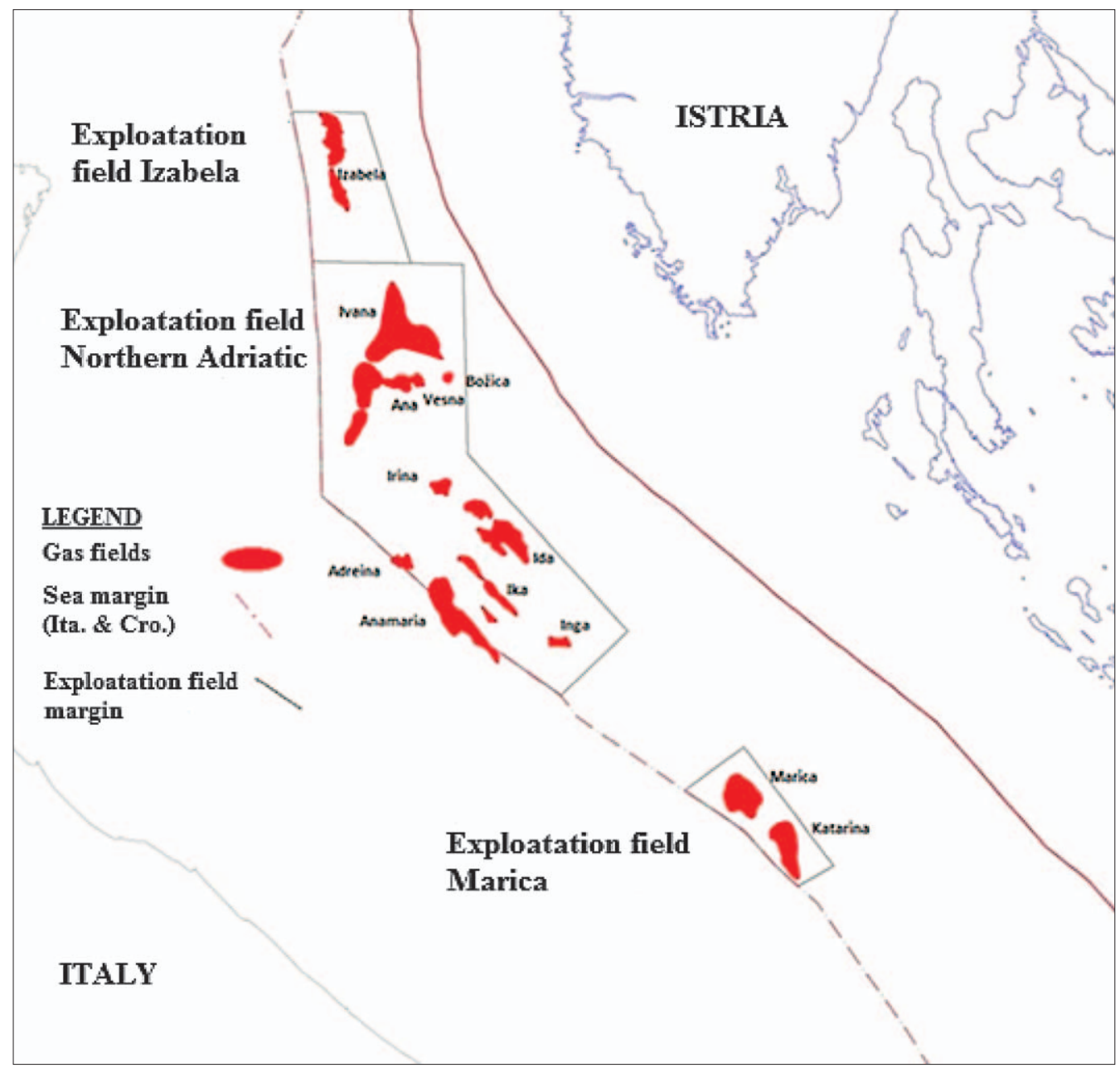

Figure 1: Exploitation fields in the Northern Adriatic (Režić, 2016)

ally vary widely with pores created because of dissolution. Dolomized limestone and dolomites are also observed (Malvić et al., 2016).

The Istria Formation is shallower and encompasses clastic sediments deposited during the Pliocene (Velić \& Malvić, 2011). The main lithology of this formation consists of marls and clays. This formation is transgressive and deposited over erosional unconformities. The thickness of the Istria Formation varies within the Po Depression, but is much thicker in the Italian part because of the proximity of the palaeo Po River and detritus source. Microfossil content of the formation is dominated by planktonic foraminiferas. The formation is very homogeneous and is not divided into members (e.g. Malvić et al., 2011).

During the Early Pleistocene, turbidities also emerged in the Croatian part and deposited inside the Ivana Formation (Velić \& Malvić, 2011), which is transgressive, with local unconformities in some places (Malvić \& Velić, 2015). The formation involves the alternation of clays and silty unconsolidated sands in which there are local proven gas reservoirs at depths from $600-1250$ meters (Malvić et al., 2011). The thickness is about 400 - 1900 meters which depends on the depositional history during the Pleistocene and Holocene (Malvić \& Velić, 2015). The alternation of turbidite and hemipelagic facies is the main characteristic of sedimentary sequences in the Croatian part of the Po Depression during the Pleistocene (e.g. Malvić et al., 2011).

Both the Mali Alan and Ivana Formations could be sources of the organic matter from which biogenic (bacterial) gas is locally created, but larger volumes are probably created and preserved in the Ivana Formation. Knowledge based on the structural position, expected migration paths and the percentage of terrestrial components in totally deposited material could lead to the following statements (Režić, 2016), (Malvić et al., 2016):

1. In the Croatian part of the Po depression, the gas is generated mostly within the Ivana Formation, in horizons with a high content of terrestrial organic matter trapped with the overlying impermeable lithofacies;

2. In the Italian part, generating horizons with biogenic gas are developed largely in the equivalents of both formations, Istria and Ivana.

3. Larger amounts of biogenic gas are created in the Italian part of the Po Depression, due to highly 


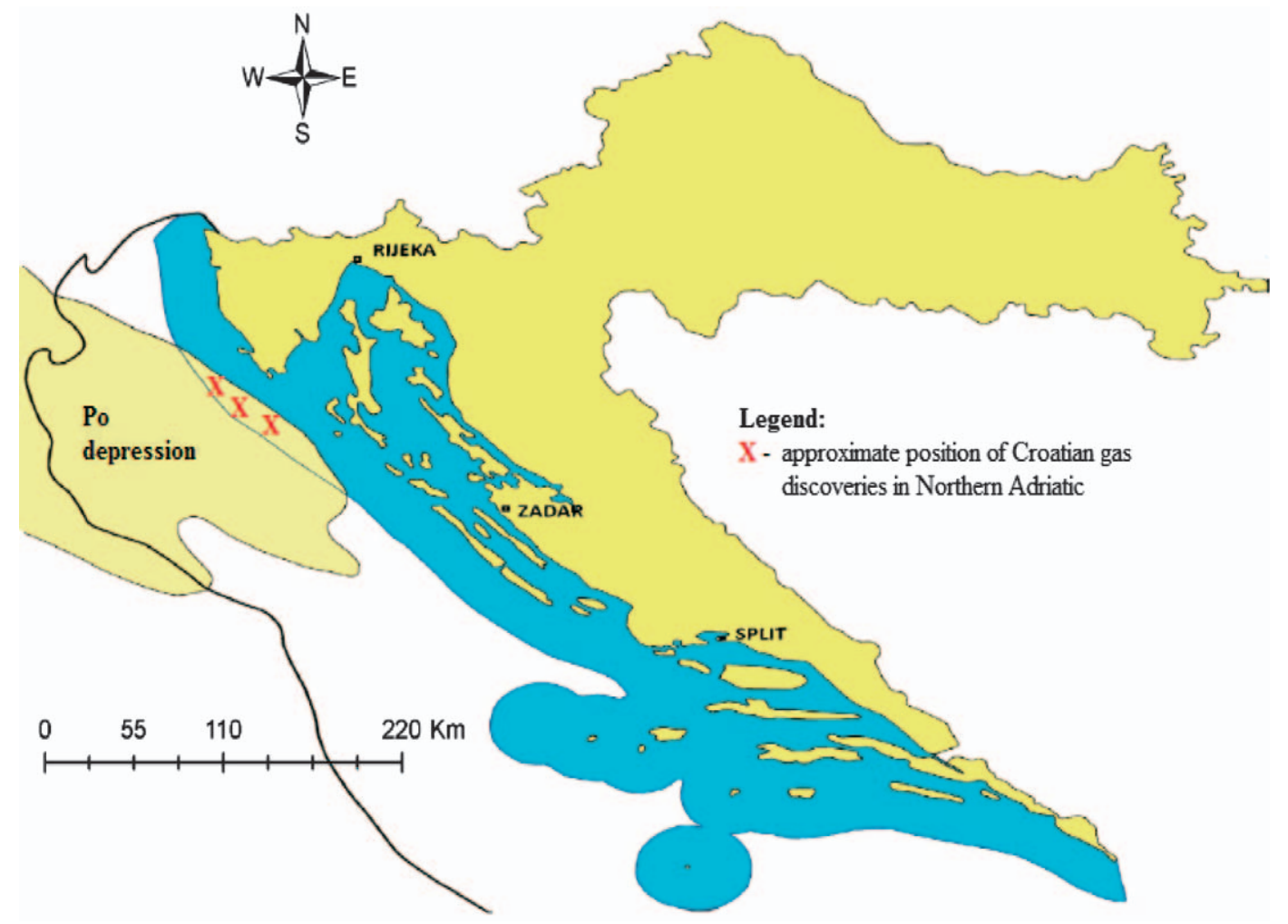

Figure 2: The Po depression (Režić, 2016)

thicker deposits, the quantity of organic matter is larger and there is less mechanical weathering;

4. Migration pathways can vary among "in situ" (primary migration), "local" (few kilometer) to "regional" (tens of kilometers). Here it is assumed that most of the gas in the Croatian part of the Po Depression had been accumulated from secondary migration that started in the Italian part $(10-30$ $\mathrm{km}$ of migration pathways) (see Figure 3).

Formations and lithology are observed in Figure 4.

\section{Geological categories}

Calculation is largely a subjective process, because every single category can be estimated by the expert engineer, from officially accepted probability tables or with additional checks of probability (so called benchmarking) following the new well data (Malvić et al., 2016). In general, the interesting stratigraphic intervals, considering hydrocarbon reservoirs, are analyzed deterministically by estimating five basic independent categories (see Figure 5) (Malvić et al. 2016):

(1) Trap;

(2) Reservoir;

(3) Migration;

(4) Source rock;

(5) Preservation of hydrocarbons.
Although the initial setting is that these are independent events, they are often intertwined and condition each other. Such a connection is too complex to be reliable and too complicated to be described, even with geomathematical methods, therefore the POS procedure is today one of the ways of such an assessment (Malvić, 2009). Events that are typical within the category are obtained on the basis of well data, well logging, seismic data, core analysis, laboratory analyses and geological interpretations. Based on this data, it is easy to choose the event probability within the variables in the table of probabilities. It is followed by the product of the values of an event and estimates the geological probability (POS). Lithological sequence can be divided into two stratigraphic intervals (Režić, 2016):

1) Pleistocene loose sands;

2) Mesozoic carbonates.

The geological probability (POS) is calculated for each observed stratigraphic interval using the following equation (1) (Malvić, 2003):

$$
P O S=p(t) \times p(r) \times p(m) \times p(s r) \times p(h c p)
$$

POS - geological probability;

$\mathrm{P}(\mathrm{t})$ - value considering trap category;

$\mathrm{P}(\mathrm{r})$ - value considering reservoir category;

$\mathrm{P}(\mathrm{m})$ - value considering migration category;

$\mathrm{P}(\mathrm{sr})$ - value considering source rock category;

$\mathrm{P}(\mathrm{hcp})$ - value considering preservation of hydrocarbons. 


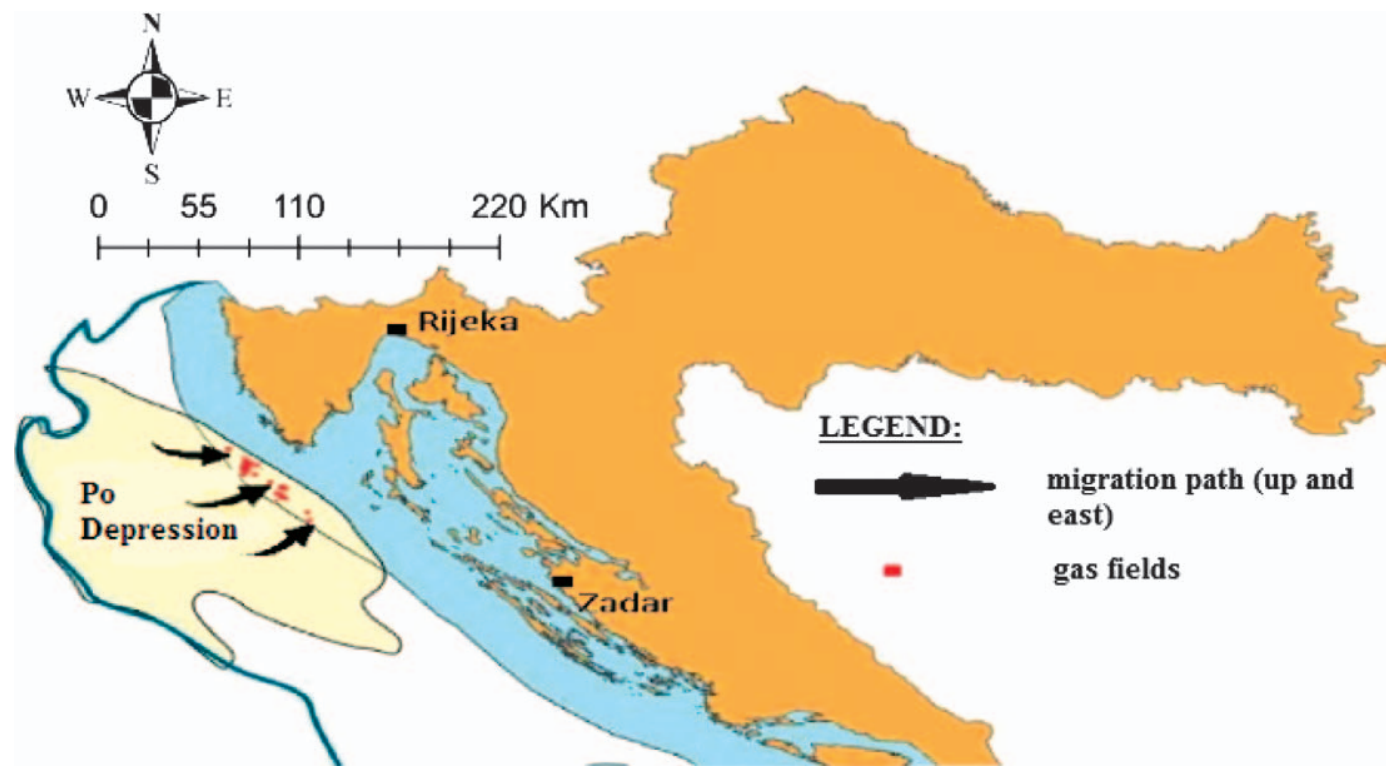

Figure 3: Main pathways of secondary migration of gas in the Po depression (Režić, 2016)

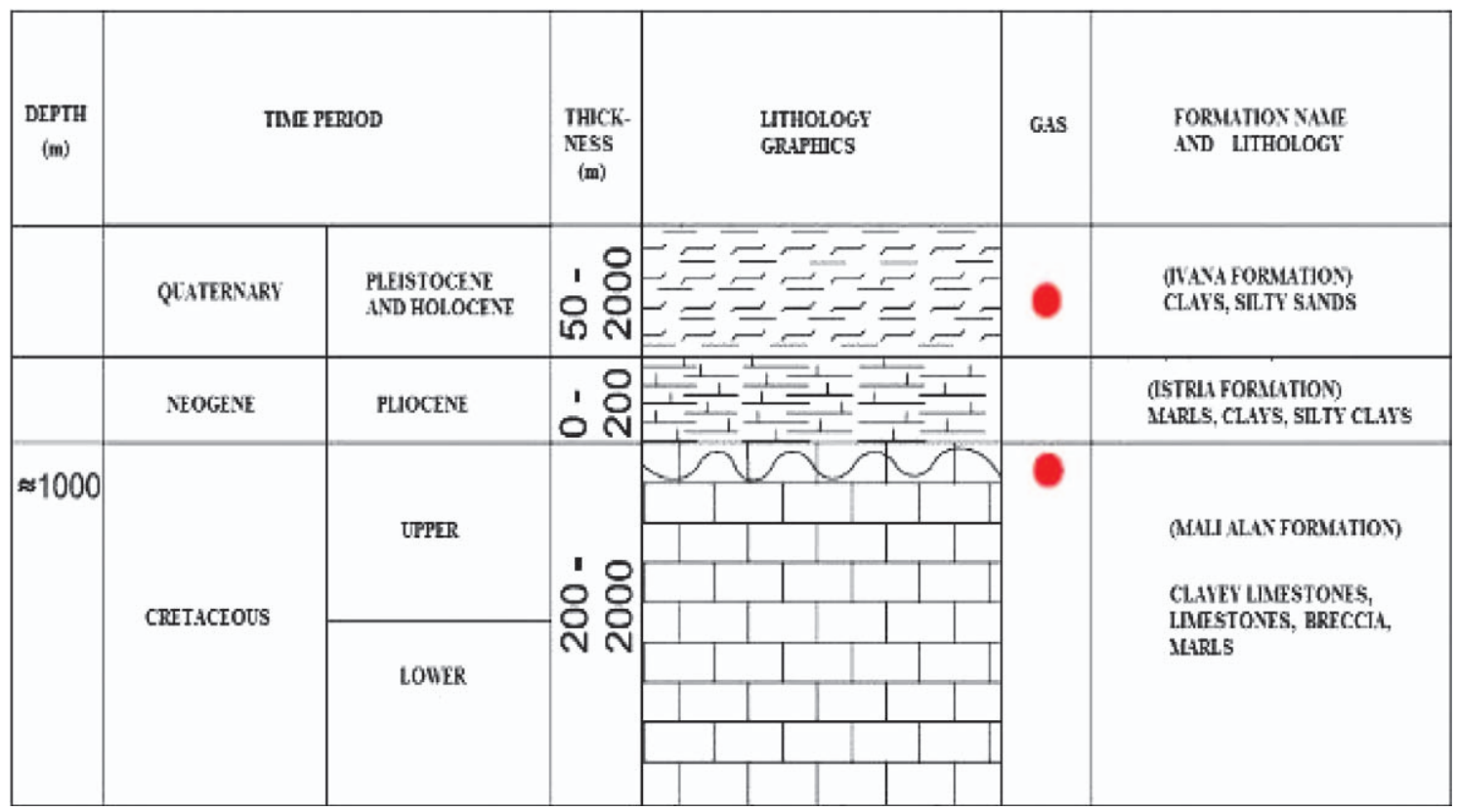

Figure 4: Lithology of main Northern Adriatic formations, Mali Alan, Istria and Ivana (Režić, 2016, modified after Velić, 2007)

\subsection{Probability classes}

The values of the variables (events) in the POS program are chosen from discrete values (deterministically) as a probability of $0-1$. Geological categories are divided and described through five, three or two probability classes. Each class has a unique numerical value in the range between 0 and 1 that describes the probability that a selected event will occur. According to such qualification, geological events are described as (Malvić et al., 2016):

1) 1.00 for an event in play/prospect described as "Certain";
2) 0.75 for an event in play/prospect described as "Very probable";

3) 0.66 for an event in play/prospect described as "Reliable"

4) 0.50 for an event in play/prospect described as "Probable";

5) 0.33 for an event in play/prospect described as "Unreliable"

6) 0.25 for an event in play/prospect described as "Low probable";

7) 0.05 for an event in play/prospect described as "Not proven / Unprobable". 


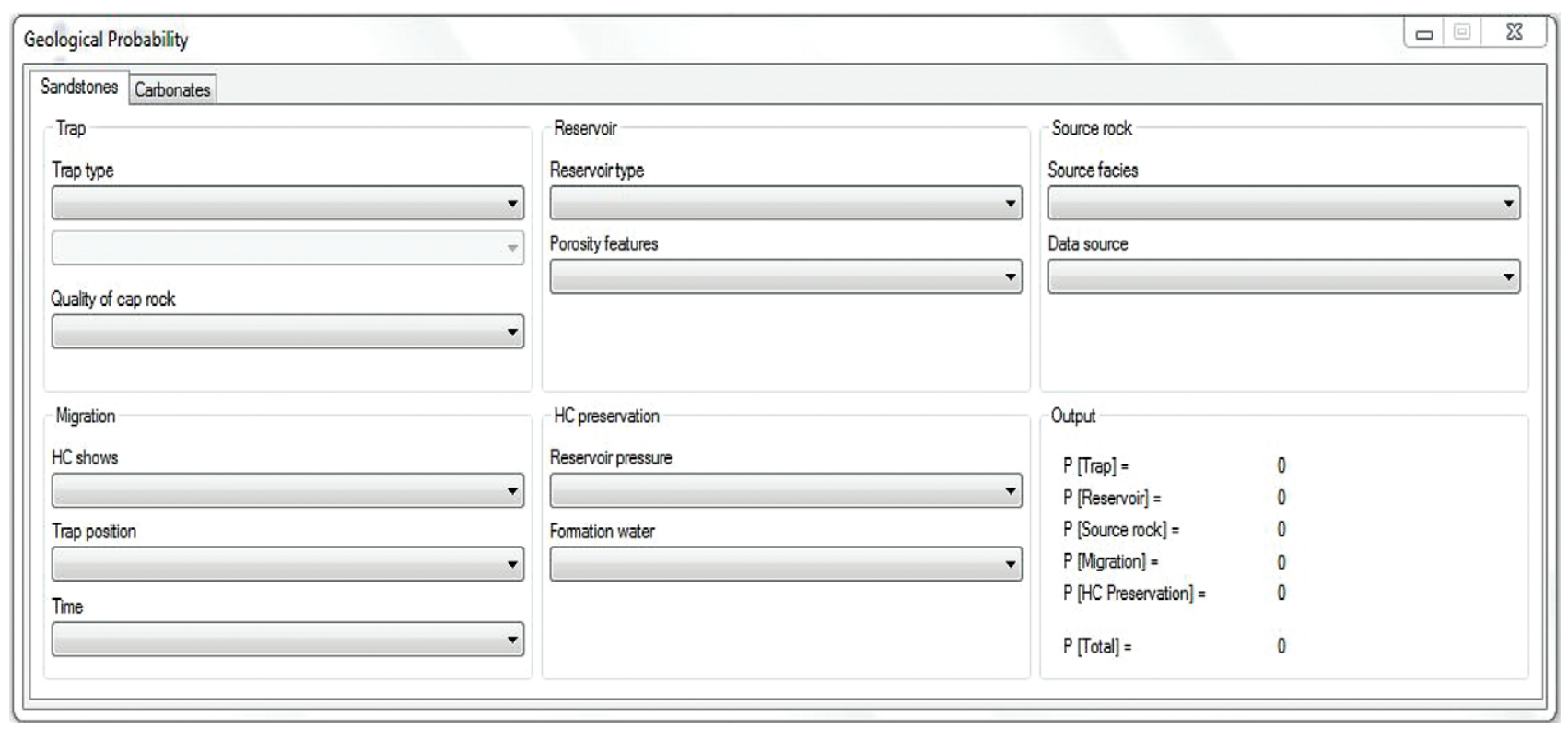

Figure 5: New freeware program interface, categories are also observed

Note that there is no value 0 in the divided probability values above and the reason is next. Just because some events have the value 0.05 and are "Not proven / Unprobable" it doesn't mean that they won't happen.

\section{Program features}

The new program is completely reviewed and adapted for analysed geological environments in the Northern Adriatic, particularly for the lithologies in the Mali Alan (Velić et. al., 2015) and Ivana Formations (Velić \& Malvić, 2011). Their value estimation is based on the frequency of occurrence of certain types of traps, reservoirs, source rocks, migrations in the area of the Croatian part of the Po Depression. To calculate the geological probability of new gas occurrence in carbonates in the category of "Trap", the events used in the subcategory "Structure" are: "Anticline or "buried hill", "Faulted anticline or diffracted rock" and "Undefined structural trap". Within the subcategory "Stratigraphic or combined" the events are: "The rocks beneath unconformities" (gas reservoir in carbonates is below the unconformity) and "Undefined stratigraphic trap". In the subcategory "Quality of cap rock" the probability division $1,0.66$ and 0.33 were used for the first time to mark three proven events ("Clayey silts and clays with a smaller portion of sand and silt", "Clayey silts and clays with a higher portion of sand and silt," and "Impermeable rock"). The category "Reservoir" is described with subcategories, "Reservoir type" and "Porosity". The subcategory "Reservoir type" is made of the events that describe what type of carbonates could be in the Ika Field. The subcategory "Porosity" is described with events depending on whether it is primary or secondary porosity in rocks that are being examined. The category "Source rock" is described with the subcategories
"Source facies" with the event "The deposition of predominantly terrestrial organic matter subsequently decomposed by bacteria", which is adapted because of the migration of gas in the area of the Croatian from the Italian part of the Po Depression. In the subcategory "Data sources" events are selected depending on whether the data is obtained by geochemical analyses or thermal modeling. The category "Migration" contains sub-categories "HC shows", "Position of trap" and "Timing". The subcategory "HC shows" is described with two events, depending on whether there are hydrocarbons present or not. The subcategory "Position of trap" simulates the events that show whether the reservoir rock is positioned in close or distant migration. The subcategory "Timing" is described with the events "The trap is younger than matured source rocks" and "Trap is older than mature source rocks." The category "HC preservation" is described with the subcategory "Reservoir pressure" and the subcategory "Formation water" that is then described with the events of "Active aquifer" and "Still aquifer". "Reservoir pressure" events are selected depending on whether a pressure in reservoir is higher, equal to or lesser than the hydrostatic pressure (Malvić et al., 2016).

The main geological settings in the Northern Adriatic could be expressed with following categories, subcategories and events. When we are talking about carbonate reservoirs then the category "Traps" are mostly faulted anticlines, sand lenses and mild anticlines. The subcategory "Quality of cap rock" describes an overlying rock section that consists of recent sediments and sands with an increased proportion of silt or clay, which are laterally extended. The category "Reservoir" is described with the types of reservoir rocks and porosity values. In the description of the category "Source rock" there is no subcategory "Maturity” with events („Late diagenesis”, 


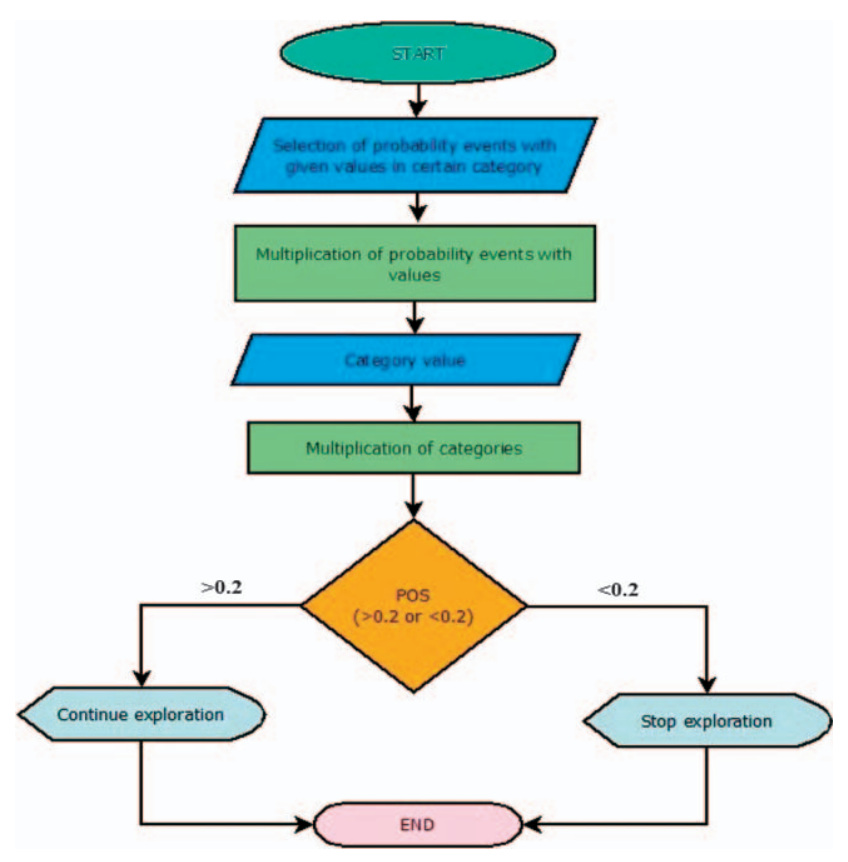

Figure 6: The algorithm of the POS

"Early catagenesis" "Catagenesis phase", "Metagenesis phase"). Instead, the geological event "Deposition of predominantly terrestrial organic matter subsequently decomposed by bacteria" is added, in order to take into account the large amounts of terrestrial organic matter that is deposited and biologically altered in the Po Depression. The category "Migration" is modified as follows - the subcategory "HC shows" is described with the events "HC production" and "HC are not observed". The subcategory "Position of trap" is described with the events: "The trap is located in a proven migration distance", "Short migration path $<=10$ km", "Long migration path $>10 \mathrm{~km}$ " and "Undefined migration distance". The category "HC preservation" is described with the subcategories "Reservoir pressure" and "Formation water" with the associated probability events (Malvić et al., 2016).

The POS for silty and pure sands is similar as for carbonates, but only adapted for such type of reservoir. To calculate the geological probability for sand reservoirs, same categories with subcategories and corresponding events like those for carbonates are used. Changes are made in subcategories like "Structural", "Stratigrafic or combined" and "Quality of cap rock". Events in the subcategories "Reservoir type" and "Porosity features" within the category "Reservoir" are also adapted for a silty sand environment (Režić, 2016).

The algorithm for the POS calculation is shown in Figure 6. The algorithm describes the simple use of the program. Upon opening the application, it is possible to choose between two reservoir rocks - carbonates and unconsolidated sands. After selection, simply by clicking certain events under categories, depending on the geological settings that are in the observed area, the pro- gram will automatically calculate the probability for a certain category and in the end the total POS. The probability value of 0.2 is a subjective assessment and is taken as the marginal value between continuing and stopping exploration because probabilities between 20 $\%-30 \%$ are still regarded large enough to continue the research and drilling with a positive outcome. Generally, in the world, where there is hydrocarbon exploration, results between $20 \%-30 \%$ are considered to be pretty high values and oil companies are willing to take the risk, because it means that in one of four or five wells there will be a discovery. The risk for "dry wells" is about $60 \%-70 \%$, which is a normal part of the work in oil and gas exploration (Malvić et al., 2016).

\section{Discussion and conclusion}

The main problem when calculating the POS was undefined source rocks in the Croatian part of the Po Depression. Because of that it is logically assumed that a major quantity of gas migrated from the Italian part of the Po Depression trough migration paths (10 - 30 kilometers). By adapting and adding the geological event "The deposition of predominantly terrestrial organic matter subsequently decomposed by bacteria" in the category "Source rock" with a probability value of 1 , calculation was made possible.

The goal was to present a simple freeware program to ease and speed up calculation by simply clicking certain events in categories. This new freeware program can be used for the probability evaluation of new gas discoveries in the Croatian part of the Po depression. Also, it can be applied to the Northern Adriatic in general but of course with minor changes in the order of geological events depending on the engineers' subjective decision and experience. It is important to emphasize that this program is completely free and available to use at no monetary cost. Hopefully, it will be used as a stepping stone in further exploration of the Northern Adriatic. The program, as freeware, is available either through the author or in the published paper on the web pages of the journal.

\section{References}

\section{Published:}

Malvić, T. (2003): Naftnogeološki odnosi i vjerojatnost pronalaska novih zaliha ugljikovodika u bjelovarskoj uleknini [Oil-Geological Relations and Probability of Discovering New Hydrocarbon Reserves in the Bjelovar Sag]. PhD thesis, University of Zagreb, Faculty of Mining, Geology and Petroleum Engineering, Zagreb, 123 p. (in Croatian and English)

Malvić, T. (2009): Stohastički pristup u determinističkom izračunu geološkoga rizika - teorija i primjer [Stohastic ap- 
proach indeterministic calculation of geological risk - theory and example]. Nafta, 60, 12, 658 - 662.

Malvić, T., Đureković, M., Šikonja, Ž., Čogelja, Z., Ilijaš, T., Kruljac, I. (2011): Istraživačke i proizvodne aktivnosti u Sjevernom Jadranu (Hrvatska) kao primjer uspješnog zajedničkog ulaganja Ine (Hrvatska) i ENI-ja (Italija) [Exploration and production activities in Northern Adriatic Sea (Croatia), successful joint venture INA (Croatia) and ENI (Italy)], Nafta, 62, 9-10, 293 - 296. (in Croatian and English)

Malvić, T., Velić, J., Cvetković, M., Vekić, M., Šapina, M. (2015): Određivanje novih pliocenskih, pleistocenskih i holocenskih litostratigrafskih jedinica u hrvatskom dijelu Jadrana (priobalju) [Definition of new Pliocene, Pleistocene and Holocene lithostratigraphic units in the Croatian part of the Adriatic Sea (shallow offshore)], Geoadria, 20, 2, 85 - 108. (in Croatian)

Malvić, T., Velić, J., Režić, M., (2016): General probability calculation of new discoveries in wider area of Ivana and Ika Gas Fields, Northern Adriatc, Croatia, Materiali in Geookolje (Materials and Geoenviroment), 63, 3; 127 137. (in English)
Režić, M. (2016): Opći model za izračun geološke vjerojatnosti novih otkrića plina na području Sjevernog Jadrana uz primjer plinskog polja Ika [General model for the calculation of geological probability associated with new gas discoveries in the Northern Adriatic with an example of the Ika gas field], Diploma Thesis University of Zagreb, Faculty of Mining, Geology and Petroleum Engineering, Zagreb, 48 p. (in Croatian with English summary)

Velić, J. (2007): Geologija ležišta nafte i plina [Geology of Oil and Gas Reservoirs], University of Zagreb, Faculty of Mining, Geology and Petroleum Engineering, Zagreb, 342 p. (in Croatian)

Velić, J., Malvić, T., (2011): Taložni uvjeti tijekom pliocena i pleistocena u Sjevernom Jadranu te moguća litostratigrafska raščlamba nastalih stijena [Depositional conditions during Pliocene and Pleistocene in Northern Adriatic and possible lithostratigraphic division of these rocks], Nafta, 62, $1-2 ; 25$ - 32. (in English and Croatian)

Velić, J., Malvić, T., Cvetković, M., Velić, I., (2015): Stratigraphy and petroleum geology of the Croatian part of the Adriatic Basin, Journal of Petroleum Geology, 38, 3, 281 - 300. (in English)

\section{SAŽETAK}

\section{Novi besplatni program za izračun geološke vjerojatnosti novih otkrića plina unutar hrvatskoga dijela Padske depresije}

Cilj rada bio je prikazati aplikaciju u obliku transparentnoga programa dostupnoga za besplatnu uporabu. Program se može koristiti za procjenu izglednosti pronalaska novih otkrića plina u hrvatskome dijelu Padske depresije. Prilikom spomenute procjene primijenjen je deterministički pristup koji uključuje 5 geoloških kategorija (zamka, ležište, matična stijena, migracija i očuvanje ugljikovodika) s određenim geološkim događajima koji ovise o geološkim značajkama podmorja sjevernoga Jadrana. Primijenjeni vrijednosni razredi uključuju pet, tri ili dvije brojčane i opisne vrijednosti prema zadanome: 1,oo za sigurne, o,75 za vrlo vjerojatne, o,66 i o,50 za vjerojatne, o,33 i o,25 za malo vjerojatne i o,05 za nedokazane događaje. Program je napravljen kao poboljšanje u smislu bržega izračuna prema prethodnoj procjeni koja se temeljila na već objavljenome hrvatskom modelu izglednosti pomoću Microsoft Excela i programa GeoProbe Modeling 1.1, koji se koristi za izračun geološke vjerojatnosti otkrića ugljikovodika za hrvatski dio Panonskoga bazena. Program je na engleskome jeziku i napravljen je u C\# programskome jeziku.

\section{Ključne riječi}

sjeverni Jadran, procjena vjerojatnosti, C\# programiranje, geološke kategorije, vjerojatnosni razredi. 